\title{
Horizontal distribution of Fukushima-derived radiocesium in zooplankton in the northwestern Pacific Ocean
}

\author{
M. Kitamura ${ }^{1}$, Y. Kumamoto ${ }^{2}$, H. Kawakami ${ }^{3}$, E. C. Cruz $^{4}$, and K. Fujikura ${ }^{1}$ \\ ${ }^{1}$ Institute of Biogeosciences, Japan Agency for Marine-Earth Science and Technology, Yokosuka, Kanagawa, Japan \\ ${ }^{2}$ Research Institute for Global Change, Japan Agency for Marine-Earth Science and Technology, Yokosuka, Kanagawa, Japan \\ ${ }^{3}$ Mutsu Institute for Oceanography, Japan Agency for Marine-Earth Science and Technology, Mutsu, Aomori, Japan \\ ${ }^{4}$ Pacific Islands Fisheries Science Center, NOAA Fisheries, Tamuning, Guam, USA
}

Correspondence to: M. Kitamura (kitamura@jamstec.go.jp)

Received: 31 December 2012 - Published in Biogeosciences Discuss.: 2 April 2013

Revised: 9 July 2013 - Accepted: 10 July 2013 - Published: 29 August 2013

\begin{abstract}
The magnitude of the 9.0 Tohoku earthquake and the ensuing tsunami on 11 March 2011, inflicted heavy damage on the Fukushima Dai-ichi nuclear power plant (FNPP1). Fission products were emitted, falling over a broad range in the Northern Hemisphere, and water contaminated with radionuclides leaked into the ocean. In this study, we described the horizontal distribution of the Fukushima-derived radiocesium in zooplankton and in seawater in the western North Pacific Ocean (500-2100 km from the FNPP1) 10 months after the accident. ${ }^{134} \mathrm{Cs}$ and ${ }^{137} \mathrm{Cs}$ were detected in zooplankton and seawater from all the stations. Because of its short half-life, the ${ }^{134} \mathrm{Cs}$ detected in our samples could only be derived from the FNPP1 accident. The highest ${ }^{137} \mathrm{Cs}$ activity in zooplankton was the same order of magnitude as it was one month after the accident, and average activity was one or two orders of magnitude higher than ${ }^{137} \mathrm{Cs}$ activities observed before the accident around Japan. Horizontally, the radiocesium activity concentrations in zooplankton were high at around $25^{\circ} \mathrm{N}$ while those in surface seawater were high at around the transition area between the Kuroshio and the Oyashio currents $\left(36-40^{\circ} \mathrm{N}\right)$. We observed subsurface radiocesium maxima in density range of the North Pacific Subtropical Mode Water and the occurrence of many diel vertical migratory zooplankton. These suggested that the high activity concentrations in the subtropical zooplankton at around $25^{\circ} \mathrm{N}$ were connected to the subsurface radiocesium and active vertical migration of zooplankton. However, the high activity concentrations of radiocesium in subsurface seawater did not necessarily correlate with the higher radiocesium activity in zooplankton. Activity concentrations of radiocesium
\end{abstract}

in zooplankton might be influenced not only by the environmental radiocesium activity concentrations but also by other factors, which are still unknown.

\section{Introduction}

The magnitude of the 9.0 Tohoku earthquake and the ensuing tsunami on 11 March 2011 inflicted heavy damage on the Fukushima Dai-ichi nuclear power plant (FNPP1). The loss of power supply and subsequent overheating, meltdowns, and hydrogen explosions at the FNPP1 resulted in airborne release of radionuclides and subsequent fallout over the land and the ocean. In addition to atmospheric fallout, water contaminated with radionuclides leaked into the ocean.

Numerical simulation showed that the radionuclides derived from FNPP1 circulated around the Northern Hemisphere (Stohl et al., 2012), and the fission products were actually detected in aerosol, gaseous, rain and snow samples collected in North America (e.g., Bowyer et al., 2011; Leon et al., 2011), Europe (e.g., Bossew et al., 2012; Masson et al., 2011), central Russia (Bolsunovsky \& Dementyev, 2011; Melgunov et al., 2012) and Taiwan (Huh et al., 2012). The radionuclides emitted from FNPP1 were also detected from terrestrial biota not only in Japan (e.g., Hashimoto et al., 2012; Higaki et al., 2012; Tagami et al., 2012) but also in North America (Thakur et al., 2012) and Europe (Cosma et al., 2011; Pittauerova et al., 2011). As compared with the terrestrial research, however, studies on the influences of the FNPP1 accident to marine biota have been scarce. 
Table 1. Radiocesium activities in zooplankton in western North Pacific Ocean 10 months after the FNPP1 accident. The radiocesium activities and biomasses are based on the dry weight. The radiocesium activities were decay corrected to the date of sampling. The uncertainty of radiocesium activity is the sum of errors due to the gamma counting, calibration, and cascade correction and is given at one sigma. SST means sea surface temperature.

\begin{tabular}{|c|c|c|c|c|c|c|c|c|c|c|}
\hline Station & $\begin{array}{r}\text { Latitude } \\
(\mathrm{N})\end{array}$ & $\begin{array}{r}\text { Longitude } \\
\text { (E) }\end{array}$ & $\begin{array}{r}\text { Depth } \\
(\mathrm{m})\end{array}$ & $\begin{array}{r}\text { Sampling } \\
\text { date }\end{array}$ & $\begin{array}{l}\text { Sampling } \\
\text { layer (m) }\end{array}$ & $\begin{array}{l}\text { SST } \\
\left({ }^{\circ} \mathrm{C}\right)\end{array}$ & Salinity & $\begin{array}{r}{ }^{134} \mathrm{Cs} \\
\left(\mathrm{Bq} \mathrm{kg-dw}^{-1}\right)\end{array}$ & $\begin{array}{r}{ }^{137} \mathrm{Cs} \\
\left(\mathrm{Bq} \mathrm{kg}-\mathrm{dw}^{-1}\right)\end{array}$ & $\begin{array}{r}\text { Biomass } \\
\left(\mathrm{g}-\mathrm{dw} \mathrm{m}^{-2}\right)\end{array}$ \\
\hline 59 & $19^{\circ} 10.1^{\prime}$ & $149^{\circ} 19.3^{\prime}$ & 5556 & 14 Jan 2012 & $0-198$ & 27.6 & 34.76 & $4.5 \pm 0.3$ & $4.7 \pm 0.2$ & 0.67 \\
\hline 62 & $21^{\circ} 10.8^{\prime}$ & $149^{\circ} 20.4^{\prime}$ & 5392 & 15 Jan 2012 & $0-218$ & 26.7 & 34.78 & $3.1 \pm 1.0$ & $5.7 \pm 1.0$ & 0.72 \\
\hline 68 & $24^{\circ} 30.0^{\prime}$ & $149^{\circ} 20.7^{\prime}$ & 5773 & 17 Jan 2012 & $0-211$ & 24.0 & 35.20 & $10.5 \pm 1.5$ & $14.9 \pm 1.3$ & 0.49 \\
\hline 71 & $26^{\circ} 30.0^{\prime}$ & $149^{\circ} 20.1^{\prime}$ & 6100 & 18 Jan 2012 & $0-209$ & 23.0 & 35.08 & $8.2 \pm 1.4$ & $13.7 \pm 1.3$ & 0.48 \\
\hline 77 & $29^{\circ} 59.2^{\prime}$ & $149^{\circ} 16.0^{\prime}$ & 6194 & 20 Jan 2012 & $0-223$ & 19.9 & 34.86 & $3.4 \pm 0.9$ & $4.6 \pm 0.9$ & 0.82 \\
\hline 82 & $32^{\circ} 30.0^{\prime}$ & $149^{\circ} 20.1^{\prime}$ & 5949 & 24 Jan 2012 & $0-194$ & 18.7 & 34.70 & $4.0 \pm 1.1$ & $4.8 \pm 1.0$ & 0.79 \\
\hline 88 & $34^{\circ} 15.1^{\prime}$ & $149^{\circ} 10.2^{\prime}$ & 6169 & 25 Jan 2012 & $0-222$ & 18.6 & 34.73 & $3.8 \pm 1.0$ & $5.2 \pm 0.9$ & 0.76 \\
\hline 98 & $37^{\circ} 25.1^{\prime}$ & $147^{\circ} 12.1^{\prime}$ & 5677 & 1 Feb 2012 & $0-234$ & 12.5 & 34.23 & $5.2 \pm 0.9$ & $8.4 \pm 0.9$ & 0.78 \\
\hline 106 & $40^{\circ} 05.1^{\prime}$ & $145^{\circ} 22.3^{\prime}$ & 5374 & 4 Feb 2012 & $0-191$ & 3.7 & 33.34 & $1.9 \pm 0.3$ & $2.2 \pm 0.1$ & 2.73 \\
\hline 112 & $41^{\circ} 44.8^{\prime}$ & $144^{\circ} 07.5^{\prime}$ & 1484 & 5 Feb 2012 & $0-173$ & 1.6 & 33.17 & $2.1 \pm 0.4$ & $2.2 \pm 0.2$ & 2.56 \\
\hline
\end{tabular}

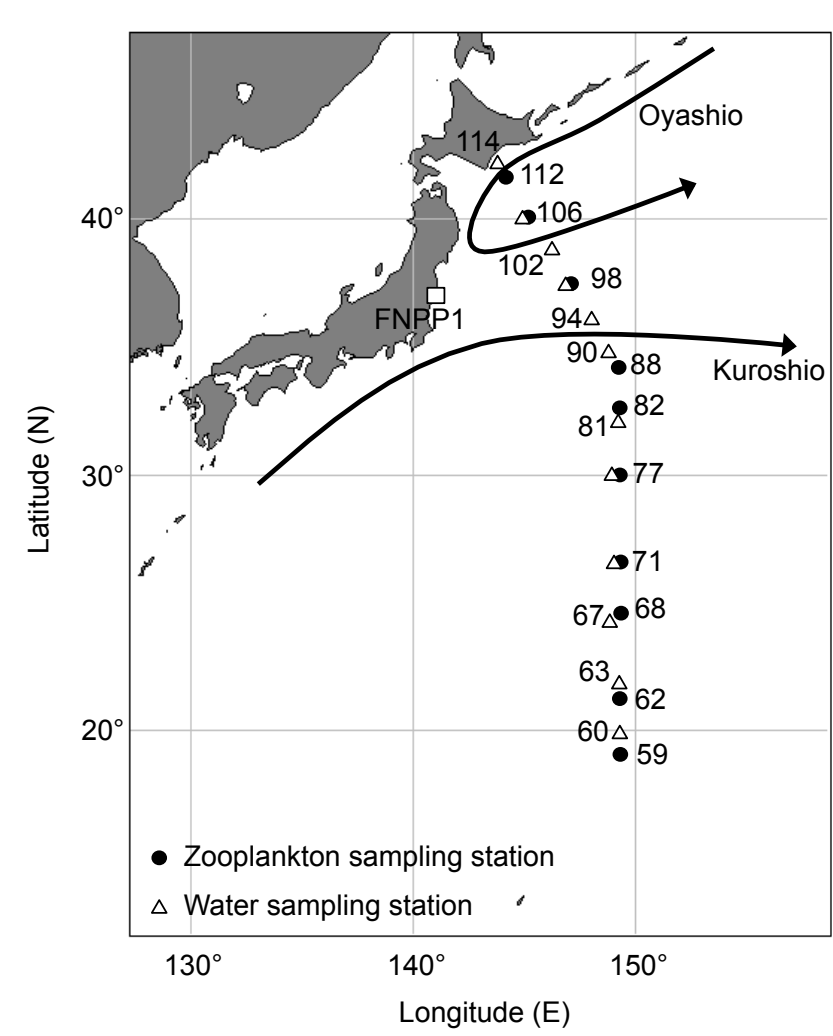

Fig. 1. Sampling locations of zooplankton and seawater samples in the western North Pacific Ocean. Black circles and white triangles denote sampling stations for zooplankton and surface seawater, respectively. The Fukushima Dai-ichi nuclear power plant is also shown as a white square in this map.

Honda et al. (2012) reported that ${ }^{137} \mathrm{Cs}$ in zooplankton at the time series stations $\mathrm{K} 2\left(47^{\circ} \mathrm{N}, 160^{\circ} \mathrm{E}, 1900 \mathrm{~km}\right.$ far from FNPP1) and $\mathrm{S} 1\left(30^{\circ} \mathrm{N}, 145^{\circ} \mathrm{E}, 900 \mathrm{~km}\right)$ one month after the Fukushima accident were two orders higher than that observed off Japan before the accident. Buesseler et al. (2012) detected the Fukushima-derived ${ }^{134} \mathrm{Cs},{ }^{137} \mathrm{Cs}$ and ${ }^{110 \mathrm{~m}} \mathrm{Ag}$ in zooplankton and mesopelagic fish collected from 30 to $600 \mathrm{~km}$ offshore of Japan's coast. Madigan et al. (2012) found that the Fukushima-derived radiocesium has also contaminated the Pacific bluefin tuna, Thunnus orientalis, which is fished off the California coast, and have concluded that the tuna transported the Fukushima-derived radionuclides across the entire North Pacific Ocean. Although most of the total fallout was simulated to fall over the North Pacific Ocean (Stohl et al., 2012), it is still uncertain whether the marine biota was contaminated with radionuclides. Here, we describe the horizontal distribution of the Fukushimaderived radiocesium in zooplankton and seawater in the western North Pacific Ocean 10 months after the accident. Previous reports that described radionuclide contamination in zooplankton provided no detail of the community structure (e.g., Buesseler et al., 2012; Honda et al., 2012). To discuss the ecological impact of radionuclide contamination on marine biota, detailed information on what kind of species the community included would be needed. In addition, taxonomic compositions of the community possibly affect radionuclide activity concentration in bulk communities because the activity concentration ratio is species specific and related to trophic level (Heldal et al., 2003). So, we describe the detailed community structures of zooplankton contaminated with the Fukushima-derived radiocesium and examine whether characters of taxonomic composition in communities influenced radionuclide activity concentrations in bulk communities.

\section{Methods}

Zooplankton and seawater samples were collected at 10 and 12 stations (Fig. 1), respectively, along the sections P10 or $\mathrm{P} 10 \mathrm{~N}$ for the World Ocean Circulation Experiment in the northwestern Pacific from January to February 2012, about 10 months after the FNPP1 accident. The southern seven 
Table 2. Temperatures, salinities and radiocesium activities in surface seawater collected in western North Pacific Ocean 10 months after the FNPP1 accident. The radiocesium activities were decay corrected to the date of sampling. The uncertainty of radiocesium activity is the sum of errors due to the gamma counting, calibration, and cascade correction and is given at one sigma. SST means sea surface temperature.

\begin{tabular}{|c|c|c|c|c|c|c|c|c|}
\hline Station & $\begin{array}{r}\text { Latitude } \\
(\mathrm{N})\end{array}$ & $\begin{array}{r}\text { Longitude } \\
\text { (E) }\end{array}$ & $\begin{array}{r}\text { Depth } \\
(\mathrm{m})\end{array}$ & Sampling date & $\begin{array}{l}\mathrm{SST} \\
\left({ }^{\circ} \mathrm{C}\right)\end{array}$ & Salinity & $\begin{array}{r}{ }^{134} \mathrm{Cs} \\
\left(\mathrm{mBq} \mathrm{kg}^{-1}\right)\end{array}$ & $\begin{array}{r}{ }^{137} \mathrm{Cs} \\
\left(\mathrm{mBq} \mathrm{kg}^{-1}\right)\end{array}$ \\
\hline 60 & $19^{\circ} 49.8^{\prime}$ & $149^{\circ} 19.8^{\prime}$ & 3691 & 16 Jan 2012 & 27.2 & 34.82 & $0.21 \pm 0.03$ & $1.72 \pm 0.11$ \\
\hline 63 & $21^{\circ} 49.8^{\prime}$ & $149^{\circ} 19.8^{\prime}$ & 5625 & 17 Jan 2012 & 26.2 & 34.82 & $0.28 \pm 0.03$ & $1.69 \pm 0.10$ \\
\hline 67 & $24^{\circ} 14.4^{\prime}$ & $149^{\circ} 01.8^{\prime}$ & 5782 & 18 Jan 2012 & 23.9 & 35.20 & $0.51 \pm 0.05$ & $2.05 \pm 0.12$ \\
\hline 71 & $26^{\circ} 30.0^{\prime}$ & $149^{\circ} 20.4^{\prime}$ & 6100 & 19 Jan 2012 & 23.0 & 35.08 & $0.69 \pm 0.06$ & $2.49 \pm 0.14$ \\
\hline 77 & $29^{\circ} 58.8^{\prime}$ & $149^{\circ} 15.0^{\prime}$ & 6194 & 23 Jan 2012 & 19.9 & 34.86 & $1.20 \pm 0.08$ & $3.01 \pm 0.16$ \\
\hline 81 & $32^{\circ} 09.6^{\prime}$ & $149^{\circ} 19.8^{\prime}$ & 5545 & 24 Jan 2012 & 18.6 & 34.72 & $0.56 \pm 0.05$ & $2.21 \pm 0.12$ \\
\hline 90 & $34^{\circ} 45.6^{\prime}$ & $148^{\circ} 52.2^{\prime}$ & 6143 & 28 Jan 2012 & 18.0 & 34.73 & $0.94 \pm 0.09$ & $2.60 \pm 0.17$ \\
\hline 94 & $36^{\circ} 04.8^{\prime}$ & $148^{\circ} 03.0^{\prime}$ & 5805 & 1 Feb 2012 & 13.0 & 34.42 & $8.44 \pm 0.50$ & $11.6 \pm 0.6$ \\
\hline 98 & $37^{\circ} 25.2^{\prime}$ & $147^{\circ} 11.4^{\prime}$ & 5677 & 4 Feb 2012 & 12.5 & 34.23 & $16.3 \pm 0.9$ & $22.7 \pm 1.1$ \\
\hline 102 & $38^{\circ} 45.0^{\prime}$ & $146^{\circ} 19.2^{\prime}$ & 5290 & 5 Feb 2012 & 10.2 & 34.23 & $18.1 \pm 1.0$ & $23.4 \pm 1.2$ \\
\hline 106 & $40^{\circ} 04.8^{\prime}$ & $145^{\circ} 22.2^{\prime}$ & 5374 & 5 Feb 2012 & 3.7 & 33.34 & $3.99 \pm 0.24$ & $6.45 \pm 0.35$ \\
\hline 114 & $42^{\circ} 10.2^{\prime}$ & $143^{\circ} 48.6^{\prime}$ & 725 & 7 Feb 2012 & 0.4 & 32.48 & $0.19 \pm 0.03$ & $1.32 \pm 0.08$ \\
\hline
\end{tabular}

zooplankton sampling stations, 59, 62, 68, 71, 77, 82 and 88 , are positioned in the subtropical region. On the other hand, the northern two stations, 106 and 112, are located in the subarctic region. Station 98 is in the transition area. The southernmost station, 59, is $2100 \mathrm{~km}$ away from the FNPP1. Zooplankton samples were obtained during the night by multioblique tows of a ring net ( $160 \mathrm{~cm}$ diameter, $0.33 \mathrm{~mm}$ mesh) equipped with a pressure sensor (SeaBird, SBE39) in its frame. Sampling depth of each tow is summarized in Table 1 . Aliquots (6-12\% of total volume) of the fresh samples were preserved with formalin to analyze community structure of zooplankton. Remaining samples used for the measurement of radiocesium were frozen at $-20{ }^{\circ} \mathrm{C}$ after all fish were removed from the sample. Surface seawaters were collected using a bucket at 12 stations (Fig. 1). Vertical distributions of radiocesium activity in seawater from the stations 90, 98 and 106 have been reported by Kumamoto et al. (2013). In the present study, those from the subtropical stations 67, 71 and 77 are reported. Deeper seawaters from $25 \mathrm{~m}$ to $800 \mathrm{~m}$ depth were collected using 12-liter Niskin-X bottles (General Oceanics Inc.) equipped with a CTD system (SBE-11 plus, Sea-Bird Electronics, Inc.). The seawater was filtered using a $0.45 \mu \mathrm{m}$ membrane filter (Millipore, HAWP14250) and acidified by $40 \mathrm{~cm}^{3}$ of concentrated nitric acid (RCI Labscan Ltd., nitric acid $70 \%$ AR) within $24 \mathrm{~h}$ after sampling on board.

After the cruise, frozen zooplankton samples were dried, pulverized, and filled up in a polypropylene container (PSU8 type, $56 \mathrm{~mm}$ in diameter and $68 \mathrm{~mm}$ in height). ${ }^{134} \mathrm{Cs}$ and ${ }^{137} \mathrm{Cs}$ radioactivities in the pulverized samples were measured by gamma-ray spectrometry using a Ge detector (ORTEC GWL-120210). The Ge detector was calibrated using mixed volume sources (RIC329, Aloka Co. Ltd.). Measurement results of ${ }^{134} \mathrm{Cs}$ and ${ }^{137} \mathrm{Cs}$ for the certified reference material (soils collected from Fukushima; the Japan Soci- ety for Analytical Chemistry, JSAC 0471-0473) agreed with the certificated values within the provided uncertainties. The detection limits of ${ }^{134} \mathrm{Cs}$ and ${ }^{137} \mathrm{Cs}$ were nearly 3.0 and $1.3 \mathrm{~Bq} \mathrm{~kg}-\mathrm{dw}^{-1}$, respectively. Because the activity of ${ }^{134} \mathrm{Cs}$ in the two samples collected from the stations 106 and 112 were below the detection level, these samples were reanalyzed using a well-type Ge detector (GCW2022-7915-30ULB, Canberra). A sample collected from the station 59 was also reanalyzed using the well-type $\mathrm{Ge}$ detector because the counting uncertainty of ${ }^{134} \mathrm{Cs}$ activities was too high (more than one third of ${ }^{134} \mathrm{Cs}$ activity). The well-type Ge detector was calibrated using mixed volume sources (EG-ML 79, Eckert and Ziegler Isotope Products). Measurement results of ${ }^{137} \mathrm{Cs}$ for IAEA standard materials (IAEA-443, -444 , and -445) agreed with the certified values within the given uncertainty range. The detection limit of ${ }^{134} \mathrm{Cs}$ and ${ }^{137} \mathrm{Cs}$ were nearly 1.3 and $0.8 \mathrm{~Bq} \mathrm{~kg} \mathrm{dw}^{-1}$, respectively. Radiocesium in the seawater sample was concentrated by an improved ammonium phosphomolybdate (AMP) method (Aoyama and Hirose, 2008) and was quantitatively separated from seawater by co-precipitation with AMP/Cs. Radiocesium activity in the AMP/Cs compound was measured at the Ogoya Underground Laboratory of the Low Level Radioactivity Laboratory of Kanazawa University using high-efficiency, ultra-low background Ge detectors (Hamajima and Komura, 2004). All radiocesium activities were decay corrected to the sampling date.

Zooplankton samples preserved with formalin were sorted into higher taxa and dried at $60^{\circ} \mathrm{C}$. The samples were then weighed and major taxa composition was determined. Species composition of the two dominant taxa, Copepoda and Euphausiacea, were analyzed on an abundance basis by microscopic observation. 

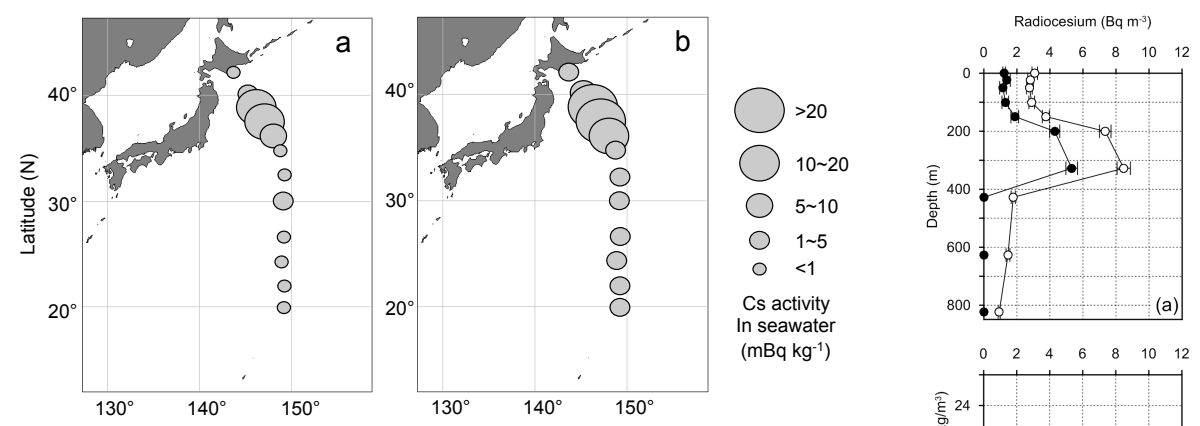

In seawate

$\left(\mathrm{mBq} \mathrm{kg}^{-1}\right)$
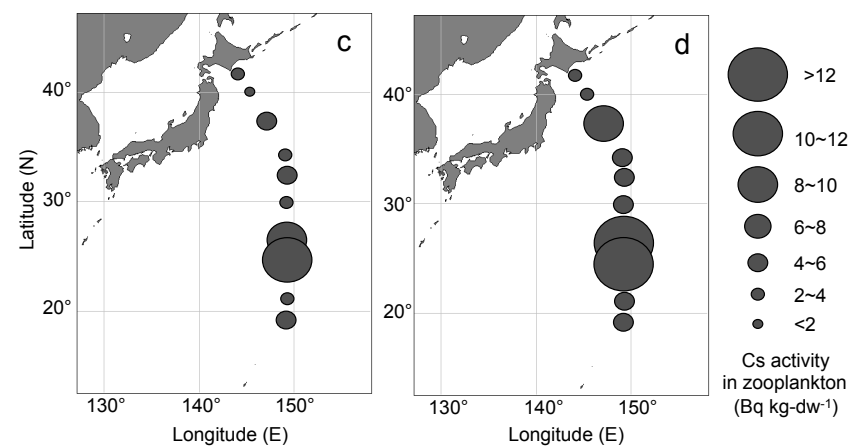

Fig. 2. Horizontal distributions of radiocesium activity concentrations in surface seawater and zooplankton in the western North Pacific Ocean 10 months after the FNPP1 accident. (a) ${ }^{134} \mathrm{Cs}$ activity in surface seawater, (b) ${ }^{137} \mathrm{Cs}$ activity in surface seawater, (c) ${ }^{134} \mathrm{Cs}$ activity in the bulk zooplankton community, and (d) ${ }^{137}$ Cs activity in the bulk zooplankton community. All the activities were decay corrected to the date of sampling.

\section{Results}

${ }^{134} \mathrm{Cs}$ in zooplankton was detected in all stations and ranged from 1.9 to $10.5 \mathrm{~Bq} \mathrm{kg-dw}{ }^{-1}$ (Table 1). The highest activity concentration was recorded in subtropical station 68 while the lowest one was in subarctic station $106 .{ }^{137} \mathrm{Cs}$ was also observed in all zooplankton samples and ranged from 2.2 to $14.9 \mathrm{~Bq} \mathrm{~kg}-\mathrm{dw}^{-1}$ (Table 1 ). High ${ }^{137} \mathrm{Cs}$ activity concentrations were observed at stations 68 and $71 .{ }^{137} \mathrm{Cs}$ activity concentrations in other stations were one order of magnitude lower than that in the two stations, and the lowest activity concentration was detected in station $106 .{ }^{134} \mathrm{Cs}$ was lower than ${ }^{137} \mathrm{Cs}$ in all the stations because of faster decay of ${ }^{134} \mathrm{Cs}$ during the 10 months after the accident and the pre-existing bomb-produced ${ }^{137} \mathrm{Cs}$.

${ }^{134} \mathrm{Cs}$ and ${ }^{137} \mathrm{Cs}$ were detected in all surface seawater samples and ranged from 0.19 to 18.1 and from 1.32 to 23.4 $\mathrm{mBq} \mathrm{kg}^{-1}$, respectively (Table 2). Radiocesium activity concentrations were high at around the transition area (stations 94, 98 and 102), while they were low in the other stations. The horizontal distributions of ${ }^{134} \mathrm{Cs}$ and ${ }^{137} \mathrm{Cs}$ activity concentrations in surface seawater did not corresponded to those in zooplankton (Fig. 2). Figure 3 shows vertical profiles of ${ }^{134} \mathrm{Cs}$ and ${ }^{137} \mathrm{Cs}$ at the three stations 67,71 and $77 .{ }^{134} \mathrm{Cs}$ was
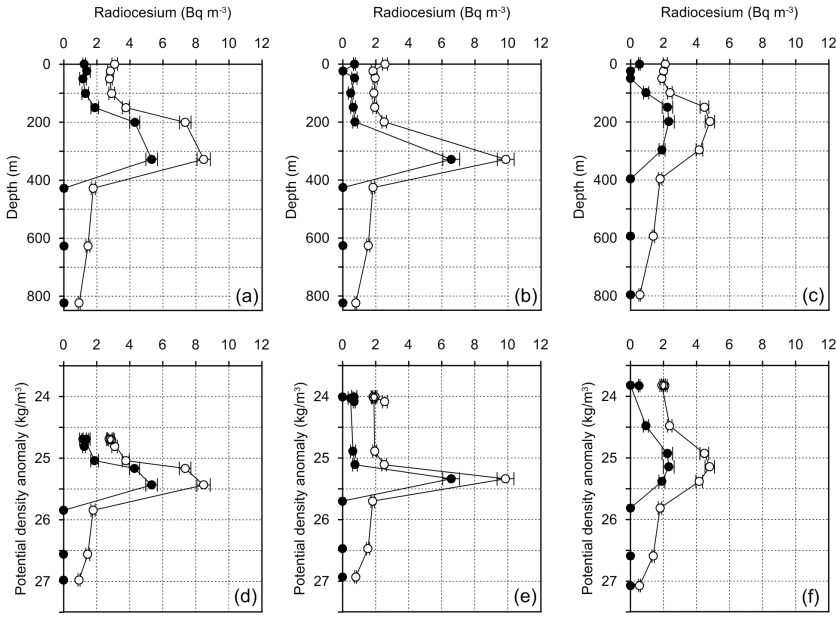

Fig. 3. Depth profiles of activity concentration of ${ }^{134} \mathrm{Cs}$ (closed circles) and ${ }^{137} \mathrm{Cs}$ (open circles) at the three subtropical stations, 77 (a), 71 (b) and 67 (c), 10 months after the FNPP1 accident. Those are also plotted against potential density anomaly $\left(\mathrm{kg} \mathrm{m}^{-3}\right)$ of the sampled seawater at the three stations, 77 (d), 71 (e) and 67 (f). The potential density is the density a parcel of water would have if it were raised adiabatically to the surface without change in salinity. The potential density anomaly, $\sigma_{\theta}\left(\mathrm{kg} \mathrm{m}^{-3}\right)$, is calculated using potential temperature $(\theta)$ and salinity $(s)$ as follows; $\sigma_{\theta}(s, \theta, 0)$ $=\rho(s, \theta, 0)-1000$, where $\rho$ indicates seawater density $\left(\mathrm{kg} \mathrm{m}^{-3}\right)$ and 0 (zero) means "at sea surface". All the activities were decay corrected to the date of sampling.

not detected below $400 \mathrm{~m}$ depth while ${ }^{137} \mathrm{Cs}$ was observed in all the samples. The ${ }^{134} \mathrm{Cs}$ and ${ }^{137} \mathrm{Cs}$ profiles had subsurface maxima from $200 \mathrm{~m}$ to $300 \mathrm{~m}$ depth $\left(\sigma_{\theta} \approx 25.3\right)$. We calculated the vertical-integrated radiocesium inventory from surface to $800 \mathrm{~m}$ depth. The activity concentrations were corrected for radioactive decay to the sampling date. The inventories of ${ }^{134} \mathrm{Cs}$ at the stations 67,71 and 77 were $520 \pm 70$, $900 \pm 90$ and $1240 \pm 100 \mathrm{~Bq} \mathrm{~m}^{-2}$, respectively. Because the inventories reported by Kumamoto et al. (2013) were decay corrected to the day of FNPP1 accident, 11 March 2011, we recalculated inventories decay corrected to the sampling date from surface to $800 \mathrm{~m}$ depth at stations 90, 98 and 106. The inventories of ${ }^{134} \mathrm{Cs}$ were $1030 \pm 70,3590 \pm 250$, and $530 \pm 40 \mathrm{~Bq} \mathrm{~m}^{-2}$, respectively.

Figure 4 indicates higher taxa composition of zooplankton on a dry weight basis at each station. Copepods were predominant in all stations except 71 , and euphausiids were also dominant throughout the study area. Pelagic snails occupied a relatively high percentage in the subtropical area. High relative biomasses of tunicates were observed at stations 77 and 98; pyrosomes and salps were dominant, respectively. Specimens of the Copepoda were identified to the species level (Table 3). Copepod diversity was high in the subtropical stations while low in the transition and subarctic area. In the subtropical stations, Calanidae, Euchaetidae and Metridinidae were abundant. Among them, 


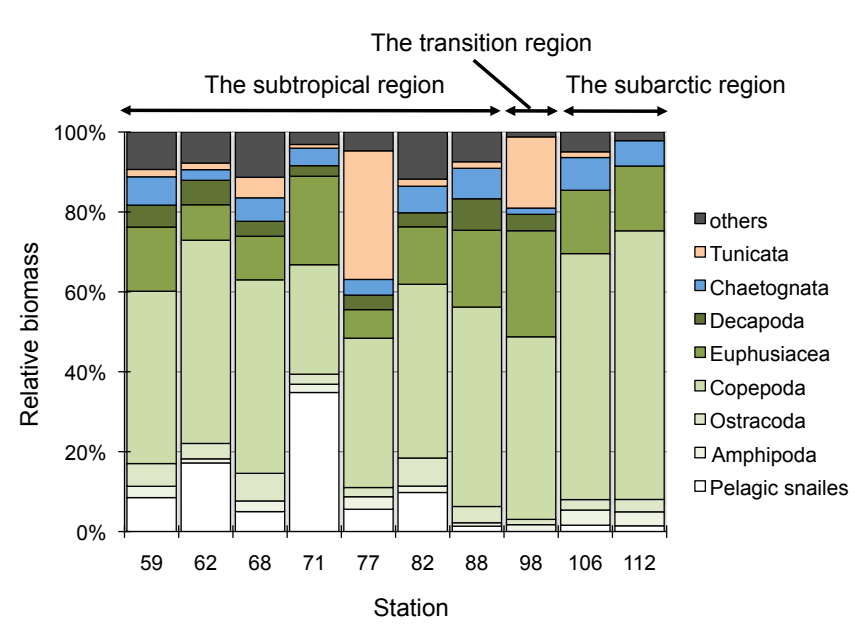

Fig. 4. Major taxa compositions of zooplankton between 0 and $200 \mathrm{~m}$ in depth from January to February 2012 in the western North Pacific Ocean. Compositions are based on the dry weight. Stations from 59 to 88 were located in subtropical region, station 98 was in the transition region, and stations 106 and 112 were in subarctic areas.

Pleuromamma gracilis (Metridinidae) was the most abundant species, which occupied up to $27 \%$ of the copepod community (station 82). In station 98 located in the transition area, Metridia pacifica (Metridinidae) and P. gracilis were abundant; $80 \%$ of copepods were occupied by these two species. In the subarctic stations, over $75 \%$ of copepods were Metridia pacifica. Among the 47 identified copepods in this study, eight species, Euchirella curticauda, M. pacifica, Paraeuchaeta elongata, Pleuromamma abdominalis, P. gracilis, Pleuromamma quadrungata, Pleuromamma scutulata, Pleuromamma xiphias, were diel vertical migrants. These migratory species occupied more than $80 \%$ on the abundance basis in the subarctic and transition regions while from $3 \%$ to $36 \%$ in subtropical stations. There was a total of 15 species of Euphausiacea identified (Table 4). Eleven of the 15 species were known as diel vertical migratory species, they occupied from 16.7 (station 68) to $100 \%$ (stations 106 and 112) on the abundance basis. As with copepods, euphausiid diversity was high in the subtropical stations while only $\mathrm{Eu}$ phausia pacifica occurred in the subarctic stations.

\section{Discussion}

Because of its short half-life, ${ }^{134} \mathrm{Cs}\left(T_{1 / 2}=2.065 \mathrm{yr}\right)$ detected in our all zooplankton and seawater samples could only be derived from the FNPP1 accident. The highest ${ }^{137} \mathrm{Cs}$ activity concentration in the zooplankton sample (14.9 Bq kg-dw ${ }^{-1}$, station 68) was the same order of magnitude as ${ }^{137} \mathrm{Cs}$ in zooplankton one month after the accident (13.5-71.5 Bq kg-dw ${ }^{-1}$, Honda et al., 2012). And the average $\left(6.6 \mathrm{~Bq} \mathrm{kg-dw}{ }^{-1}\right)$ was one or two orders higher than ${ }^{137} \mathrm{Cs}$ in zooplankton off Japan before the accident $(0.09$
0.4 ${\mathrm{Bq} \mathrm{kg}-\mathrm{dw}^{-1}}^{-1}$, Kaeriyama et al., 2008a). ${ }^{137} \mathrm{Cs}$ activity concentrations in zooplankton 10 months after the FNPP1 accident were concluded to be still higher than those before the accident.

Activity concentrations of ${ }^{134} \mathrm{Cs}$ and ${ }^{137} \mathrm{Cs}$ in surface seawater were lower than those observed one month after the accident (Buesseler et al., 2012; Honda et al., 2012), and the lowest one was observed in the northernmost station, 114, located in the Coastal Oyashio area. The Coastal Oyashio Water is strongly influenced by outflow from the Sea of Okhotsk (Katsumata and Yasuda, 2010; Sakamoto et al., 2010), and ${ }^{137} \mathrm{Cs}$ activity concentrations in seawater there were not elevated after the FNPP1 accident (Karasev, 2012). The low radiocesium activity in seawater in station 114 was possibly due to the Coastal Oyashio Water. On the other hand, the radiocesium activity concentrations in surface seawater around the transition region were high. The high activity concentrations were also observed in the winter mixed layer (Kumamoto et al., 2013). These were possibly due to advection of the contaminated waters from the coastal area of the FNPP1. Aoyama et al. (2013) and Kaeriyama et al. (2013) also reported eastward movement of direct discharged radiocesium from FNPP1 in the transition region.

As for concerns in the subtropical area, dilution of seawater by different water bodies with different $T / S$-signatures or vertical transportation of radiocesium attached with the sinking particles into deep layers would be possible explanations for the low radiocesium activity concentrations in surface seawater. The bomb-produced ${ }^{137} \mathrm{Cs}$, which was derived from the global fallout of the nuclear weapon tests in the 1950s and 1960s, in seawater sometimes peaked at the subsurface in the subtropical northwestern Pacific (Aoyama et al., 2008; Povinec et al., 2003). The ${ }^{137}$ Cs subsurface maxima were in the density ranges of North Pacific Subtropical Mode Water (NPSMW; $\sigma_{\theta} \approx 25.5$ ) or Lighter Central Mode Water (LCMW; $\sigma_{\theta} \approx 26.0$ ), and the ${ }^{137}$ Cs has been transported from the subarctic region to the subtropics and tropics as a result of subduction (Aoyama et al., 2008). The subsurface maxima of the Fukushima-derived radiocesium at subtropical stations 67, 71, 77 (Fig. 3) and 90 (Kumamoto et al., 2013) in the density range of NPSMW were also observed. Those also might be transported from subarctic to subsurface in these stations by subduction.

In this study, horizontal distribution patterns did not correspond between radiocesium activity concentrations in zooplankton and those in surface seawater. That is to say, ${ }^{134} \mathrm{Cs}$ and ${ }^{137} \mathrm{Cs}$ in zooplankton were high at around $25^{\circ} \mathrm{N}$ (stations 68 and 71), while higher activity concentrations in surface seawater were observed around the transition area. Because zooplankton communities included many diel vertical migratory species (Tables 3-4), contaminated radiocesium in zooplankton might be derived not only from surface but also subsurface radiocesium. It is possible that the subsurface radiocesium observed in the depth range of NPSMW was an important source for contamination in zooplankton 
Table 3. Copepods collected from western North Pacific Ocean 10 months after the FNPP1 accident. Asterisks show diel vertical migratory species.

\begin{tabular}{|c|c|c|c|}
\hline Taxa & Station occurred & Taxa & Station occurred \\
\hline Calanoida & & Calanoida (continued) & \\
\hline Acartidae & & Euchaetidae (continued) & \\
\hline Acartidae spp. & $59,62,68,71,77,82,88$ & Paraeuchaeta longicornis & $68,71,82,88$ \\
\hline Aetideidae & & Paraeuchaeta media & 62,68 \\
\hline Aetideus acutus & $59,62,68,71,77,82,88$ & Paraeuchaeta spinosa & 71 \\
\hline Eucirella amoena & 71 & Paraeuchaeta tuberculata & 59,77 \\
\hline Euchirella curticauda* & 71,88 & Heterorhabdidae & \\
\hline Gaetanus minor & 71 & Heterorhabdidae spp. & $59,62,68,71,77,82,88,112$ \\
\hline Gaetanus spp. & $68,98,112$ & Heterorhabdus papilliger & 71 \\
\hline Undeuchaeta plumosa & 77 & Heterorhabdus subspinifrons & 77 \\
\hline Arietelidae & & Heterorhabdus vipera & 62,68 \\
\hline Arietellus sp. & 59 & Lucicutiidae & \\
\hline Augaptilidae & & Lucicutia flavicornis & $59,62,68,71,77,82,88$ \\
\hline Augaptilidae sp. & 62 & Lucicutia gaussae & 68 \\
\hline Haloptilus acutifrons & 71 & Metridinidae & \\
\hline Haloptilus longicornis & $59,62,68,71$ & Metridia pacifica* & $98,106,112$ \\
\hline Haloptilus ornatus & 59 & Pleuromamma abdominalis* & $59,62,68,71,77,82,88,98$ \\
\hline Haloptilus spiniceps & 71 & Pleuromamma gracilis* & $59,62,68,71,77,82,88,98$ \\
\hline Haloptilus spp. & $68,71,77,82,88$ & Pleuromamma quadrungrata* & $68,71,77$ \\
\hline Calanidae & & Pleuromamma scutulata* & 106,112 \\
\hline Calanus spp. & $62,68,71,77,82,88,98$ & Pleuromamma xiphias* & 59,98 \\
\hline Canthocalanus pauper & 62,68 & Paracalanidae & \\
\hline Cosmocalanus darwini & $59,68,71,77,82,88$ & Paracalanus spp. & 82,88 \\
\hline Nannocalanus minor & $59,62,71,77,82,88$ & Phaennidae & \\
\hline Neocalanus gracilis & $68,71,77$ & Phaenna spinifera & 71,82 \\
\hline Neocalanus spp. & 106,112 & Phaennidae spp. & 98 \\
\hline Calocalanidae & & Xanthocalanus pinguis & 59,62 \\
\hline Calocalanidae sp. & 88 & Xanthocalanus spp. & 59 \\
\hline Candaciidae & & Pontellidae & \\
\hline Candacia bipinnata & 77 & Pontellina morii & 59 \\
\hline Candacia catula & 59 & Pontellina plumata & 62 \\
\hline Candacia ethiopica & 62 & Pseudocyclopidae & \\
\hline Paracandacia bispinosa & 59,71 & Pseudocyclopidae spp. & 62,71 \\
\hline Paracandacia truncata & 62,68 & Tharybidae & \\
\hline Centropagidae & & Tharybidae sp. & 98 \\
\hline Centropages elongatus & $59,62,71$ & Undinula vulgaris & 82 \\
\hline Centropages violaceus & 77 & Cyclopoida & \\
\hline Clausocalanidae & & Oithonidae & \\
\hline Clausocalanus spp. & $59,62,71,77,82,88,98$ & Oithona spp. & $59,62,68,71,82,88,98,112$ \\
\hline Microcalanus pygmaeus & 98 & Poecilostomatoida & \\
\hline Pseudocalanus sp. & 98 & Corycaeidae & \\
\hline Eucalanidae & & Corycaeidae spp. & $59,62,68,71,77,82,88,98$ \\
\hline Eucalanus crassus & 82 & Oncaeidae & \\
\hline Eucalanus spp. & $62,68,71,77,82,88,98$ & Oncaeidae spp. & $59,62,68,71,77,82,88$ \\
\hline Rhincalanus cornutus & 82,88 & Sapphirinidae & \\
\hline Euhaetidae & & Copilia quadrata & 59 \\
\hline Euchaeta rimana & 59,62 & Copilia mirabilis & 71,82 \\
\hline Eucaetidae sp. & $59,62,68,71,77,82$ & Copilia spp. & 62,68 \\
\hline Paraeuchaeta elongata* & 112 & Sapphirina spp. & $62,68,71,77$ \\
\hline
\end{tabular}

in subtropical stations. However, high activity concentrations of radiocesium in subsurface seawater did not necessarily correlate with higher radiocesium activity in zooplankton. A significant relationship was not recognized between verticalintegrated inventories of ${ }^{134} \mathrm{Cs}$ activity in seawater and ${ }^{134} \mathrm{Cs}$ activity in bulk zooplankton communities (Fig. 5). In addition, relative abundances of vertical migrants were not so high in the stations 68 and 71 compared to those in other subtropical stations (Fig. 6).

We also examined whether other several biological factors influenced radiocesium activity concentrations in bulk zooplankton communities. Because the concentration ratio of radiocesium in biota is species specific and higher stable or radiocesium concentrations were observed from animals in higher trophic levels (Heldal et al., 2003; Kaeriyama et 
Table 4. Occurrences of Euphausiacea in western North Pacific Ocean 10 months after the FNPP1 accident with notes on their vertical distribution during the day and the night. Asterisks show diel vertical migratory species. Euphausia spp. and Stylocheiron spp. were unidentified juvenile or damaged specimens. SML means surface mixed layer.

\begin{tabular}{lrrrl}
\hline Species & Stations occurred & \multicolumn{3}{c}{ Depth range (m) of distribution } \\
\cline { 3 - 5 } & & Day & Night & References \\
\hline Euphausia brevis* & $59,68,71$ & $0-300$ & $0-100$ & Sawamoto (1997) \\
Euphausia diomedeae* & 77 & $100-300$ & $0-100$ & Sawamoto (1997) \\
Euphausia gibboides* & 71,88 & $300-700$ & $0-300$ & Sawamoto (1997) \\
Euphausia mutica* & $59,62,82$ & $100-500$ & $0-100$ & Sawamoto (1997) \\
Euphausia pacifica* & $98,106,112$ & $0-100$ & $50-400$ & Taki (2008) \\
Euphausia recurva* & $71,77,82,88$ & $100-500$ & $0-100$ & Sawamoto (1997) \\
Euphausia similis* & 82 & $200-500$ & $100-200$ & Sawamoto (1997) \\
Euphausia tenera* & $59,82,88$ & $100-300$ & $0-200$ & Sawamoto (1997) \\
Euphausia spp. & $68,77,82,88$ & & & \\
Stylocheiron affini & $59,71,77,82$ & $0-400$ & $0-400$ & Sawamoto (1997) \\
Stylocheiron abbreviatum & 82,88 & $100-600$ & $100-600$ & Sawamoto (1997) \\
Stylocheiron shumii & $62,71,82$ & $0-200$ & $0-200$ & Sawamoto (1997) \\
Stylocheiron spp. & $62,68,71,88$ & & & \\
Thysanoessa inspinata & 98 & $25-150$ & $0-150$ & Taki (2011) \\
Thysanoessa longipes* & 98 & $140-300$ & $0-140$ & Sawamoto (1997) \\
Thysanopoda aequalis* & $59,62,71$ & $300-600$ & SML & Sawamoto (1997) \\
Thysanopoda tricuspidata* & 71 & $100-500$ & $50-200$ & Sawamoto (1997) \\
\hline
\end{tabular}

Table 5. Classification for feeding habits of zooplankton according to Lalli and Persons (1997) and Ohtsuka and Nishida (1997).

\begin{tabular}{lll}
\hline Particle feeder & Detritivore & Carnivore \\
\hline Pelagic snails & Ostracoda & Cnidaria \\
Copepoda & Copepoda & Cephalopoda \\
Acartidae & Phaennidae & Polychaeta \\
Aetideidae except Euchirella & Oncaeidae & Amphipoda \\
Calanidae & Tharybidae & Copepoda \\
Calocalanidae & & Arietelidae \\
Centropagidae & & Augaptilidae \\
Clausocalanidae & & Candaciidae \\
Eucalanidae & & Corycaeidae \\
Lucicutiidae & & Euchaetidae \\
Metridinidae & & Euchirella \\
Paracalanidae & & Heterorhabdidae \\
Pseudocyclopidae & & Pontellina \\
Oithonidae & & Sapphirinidae \\
Tunicata & & Euphausiacea \\
& & Decapoda \\
& & Stomatopoda larvae \\
& & Chaetognatha \\
\hline
\end{tabular}

al., 2008b), we focused on taxa compositions and relative biomass of carnivores as biological factors. The correlations between relative biomass (\%) of each taxon in each community and ${ }^{134} \mathrm{Cs}$ activity concentration in the community are shown in Fig. 7a-h. Significant correlation was not detected from all taxa. Previously, Kaeriyama et al. (2008a) reported that ${ }^{137} \mathrm{Cs}$ activity concentration in zooplankton samples were high when gelatinous zooplankton (Cnidaria, Chaetognatha and Tunicata) was abundant in the samples.

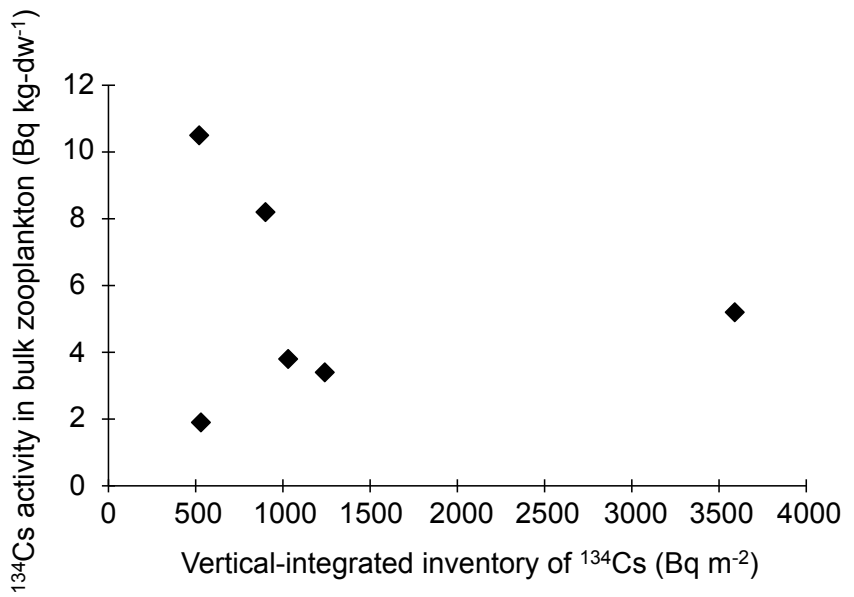

Fig. 5. Relationship between vertical-integrated inventory of ${ }^{134} \mathrm{Cs}$ $\left(\mathrm{Bq} \mathrm{m}^{-2}\right)$ and ${ }^{134} \mathrm{Cs}$ activity concentration in bulk zooplankton community $\left(\mathrm{Bq} \mathrm{kg}-\mathrm{dw}^{-1}\right)$. All the activities were decay corrected to the date of sampling.

However, such a phenomenon was not recognized in this study (Fig. 7i). Although we analyzed species compositions of the two dominant taxa, Copepoda and Euphausiacea, no species whose distribution corresponded with those of ${ }^{134} \mathrm{Cs}$ and ${ }^{137} \mathrm{Cs}$ in bulk zooplankton communities was recognized. These results suggested that the taxonomic composition of zooplankton did not influence the radiocesium in the bulk zooplankton community. We also hypothesized and examined that the relative biomass of carnivores had an effect 


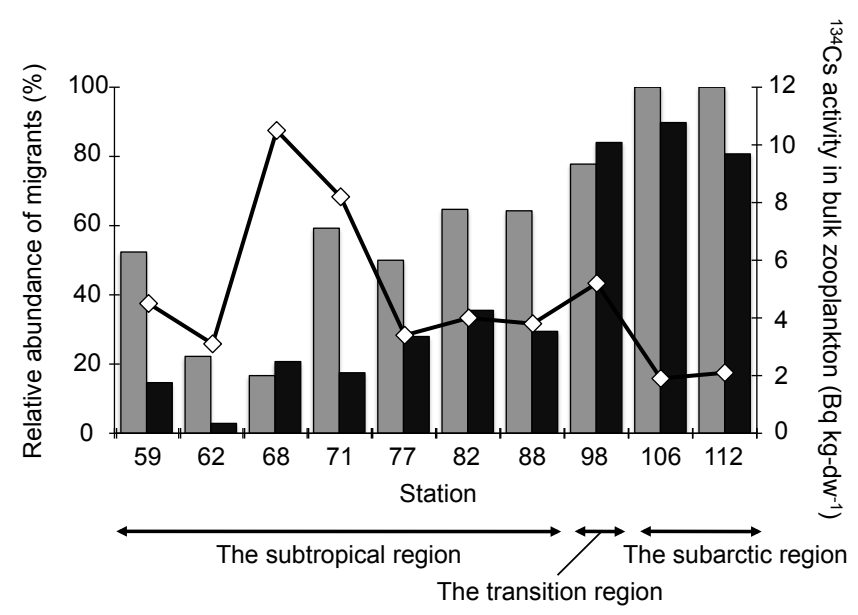

Fig. 6. Relative abundance (\%) of diel vertical migratory species of euphausiids (gray bar) and copepods (black bar) in the euphausiid and copepod communities, respectively, in each station. A line graph shows spatial change of ${ }^{134} \mathrm{Cs}$ activity concentrations decay corrected to the sampling date in bulk zooplankton communities at the 10 stations in western North Pacific 10 months after the FNPP1 accident.

on radiocesium activity concentration in bulk zooplankton. Feeding habits of zooplankton were classified according to Lalli and Persons (1997) and Ohtsuka and Nishida (1997) (Table 5). As shown in Fig. 7j, however, the correlation between the relative biomass of carnivores and ${ }^{134} \mathrm{Cs}$ activity concentration in bulk zooplankton was not significant. Consequently, it is difficult to explain the high Cs activity concentrations in zooplankton at around $25^{\circ} \mathrm{N}$ by the taxa composition or relative biomass of carnivores.

Time lag is another possible explanation for high radiocesium activity in zooplankton at around $25^{\circ} \mathrm{N}$. Because radiocesium accumulates in muscle or hepatopancreas of marine animals (Eisler, 2010) and uptake of ${ }^{137} \mathrm{Cs}$ from seawater by zooplankton was faster than excretion (Thomann, 1981), the radiocesium activity concentration in zooplankton is influenced by environmental activity concentrations not only during the sampling but also before the cruise. In stations 68 and 71, activity concentrations of ${ }^{134} \mathrm{Cs}$ and ${ }^{137} \mathrm{Cs}$ in seawater were possibly higher than that in other areas before the cruise. Actually, an atmospheric model simulated the east-west band of high radiation, which, due to radioactive aerosols moved by boundary layer transport, was located between $20^{\circ} \mathrm{N}$ and $30^{\circ} \mathrm{N}$ one month after the FNPP1 accident (Huh et al., 2012). This suggests high atmospheric deposition of radiocesium into the ocean at around $25^{\circ} \mathrm{N}$ before our research cruise.

Finally, we discuss a potential impact of the radiocesium contamination in zooplankton on oceanic ecosystems. Zooplankton communities contaminated with the Fukushimaderived radiocesium included many kinds of diel vertical migratory species. These migrants move between higher and

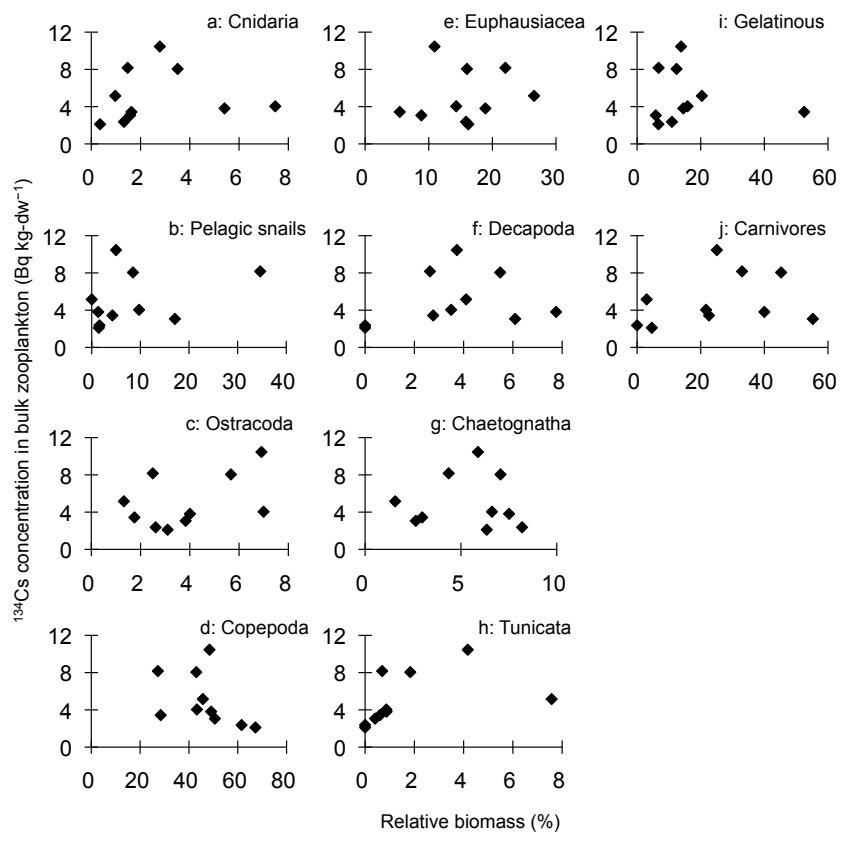

Fig. 7. Relationships between relative biomass of each taxon and ${ }^{134} \mathrm{Cs}$ activity concentration in bulk zooplankton communities (ah), between relative biomass of gelatinous zooplankton (Cnidaria, Chaetognatha and Tunicata) and ${ }^{134} \mathrm{Cs}$ in bulk zooplankton (i), and between relative biomass of carnivores and ${ }^{134} \mathrm{Cs}$ in bulk zooplankton (j). All the activities were decay corrected to the date of sampling.

lower radiocesium activity layers in a diel cycle. In the subarctic/transitional regions where radiocesium activity concentrations in surface seawater was higher than that in the subsurface layer, accumulated radiocesium in the migrant's bodies might be transported downward and, consequently, radiocesium might be accumulated into the mesopelagic food web. Recently, Madigan et al. (2012) reported that Pacific bluefin tuna transported the Fukushima-derived radiocesium from around Japan to California waters. They discussed that sea turtles, salmon and migratory birds may also be transport vectors of the Fukushima-derived radionuclides. Our results suggest that marine animals may transport the radionuclides not only horizontally but also vertically. Although we studied the Fukushima-derived radiocesium contamination in zooplankton based on the materials collected from surface layers, the contamination in mesopelagic communities should be investigated in the future. Direct influence by high radiocesium activity in seawater correlated with the mode waters and vertical transportation of radiocesium through the active migration of zooplankton may be key processes of contaminations in subtropical and subarctical/transitional mesopelagic communities, respectively. 


\section{Conclusions}

${ }^{134} \mathrm{Cs}$ and ${ }^{137} \mathrm{Cs}$ were detected in zooplankton and seawater samples collected from the western North Pacific (500$2100 \mathrm{~km}$ from the FNPP1) 10 months after the FNPP1 accident. Because of its short half-life, detected ${ }^{134} \mathrm{Cs}$ could only be derived from the accident. Radiocesium activities in zooplankton were high at around $25^{\circ} \mathrm{N}$, which does not correspond with the horizontal distribution pattern of radiocesium activities in surface seawater. We also observed subsurface radiocesium maxima in the density range of NPSMW in several subtropical stations. Zooplankton communities included many diel vertical migrants. Both results suggested that contaminated radiocesium in zooplankton were derived from subsurface radiocesium though the vertical migration of zooplankton in the subtropical stations. However, high activity concentrations of radiocesium in subsurface seawater did not necessarily correlate with higher radiocesium activity in zooplankton. Activity concentrations of radiocesium in zooplankton might be influenced not only by the environmental radiocesium activity concentration but also by other factors, which are still unknown.

Acknowledgements. We thank the captain and crew of the $\mathrm{R} / \mathrm{V}$ Mirai, marine technicians from the Marine Works Japan, Inc., and from the Global Ocean Development, Inc., for their support during sample collection on board. We are grateful to Hideki Kaeriyama, Jota Kanda and Francine Fiust for their constructive comments on an earlier version of the manuscript. This work was partially supported by MEXT KAKENHI grant number 24110005 .

Edited by: H. Nies

\section{References}

Aoyama, M. and Hirose, K.: Radiometric determination of anthropogenic radionuclides in seawater, in: Analysis of Environmental Radionuclides, Radioactivity in the Environment, vol. 2, edited by: Povinec, P. P., Elsevier, Amsterdam, London, 137-162, 2008.

Aoyama, M., Hirose, K., Nemoto, K., and Takatsuki, Y.: Water masses labeled with global fallout ${ }^{137} \mathrm{Cs}$ formed by subduction in the North Pacific. Geophy. Res. Lett., 35, L01604, doi:10.1029/2007GL031964, 2008.

Aoyama, M., Uematsu, M., Tsumune, D., and Hamajima, Y.: Surface pathway of radioactive plume of TEPCO Fukushima NPP1 released ${ }^{134} \mathrm{Cs}$ and ${ }^{137} \mathrm{Cs}$, Biogeosciences, 10, 30673078, doi:10.5194/bg-10-3067-2013, 2013.

Bolsunovsky, A. and Dementyev, D.: Evidence of the radioactive fallout in the center of Asia (Russia) following the Fukushima nuclear accident, J. Environ. Radioact., 102, 1062-1064, 2011.

Bossew, P., Kirchner, G., De Cort, M., de Vries, G., Nishev, A., and de Felice, L.: Radioactivity from Fukushima Dai-ichi in air over Europe; part 1: spatio-temporal analysis, J. Environ. Radioact., 114, 22-34, 2012.

Bowyer, T. W., Biegalski, S. R., Cooper, M., Eslinger, P. W., Haas, D., Hayes, J. C., Miley, H. S., Strom, D. J., and Woods, V.: El- evated radioxenon detected remotely following the Fukushima nuclear accident, J. Environ. Radioact., 102, 681-687, 2011.

Buesseler, K. O., Jayne, S. R., Fisher, N. S., Ryphina, I. I., Baumann, H., Baumann, Z., Breier, C. F., Douglass, E. M., George, J., Macdonald, A. M., Miyamoto, H., Nishikawa, J., Pike, S. M., and Yoshida, S.: Fukushima-derived radionuclides in the ocean and biota off Japan, Proc. Natl. Acad. Sci. USA, 109, 5984-5988, 2012.

Cosma, C., Iurian, A. R., Nita, D. C., Begy, R., and Cindea, C.: Considerations about the presence of Fukushima radionuclides in the NW part of Romania, Rom. Jour. Phys., 56, 1199-1207, 2011.

Eisler, R.: Compendium of trace metals and marine biota: vol. 1: plants and invertebrates, Elsevier, Oxford, 610 pp., 2010.

Hamajima, Y. and Komura, K.: Background components of Ge detectors in Ogoya underground laboratory, Appl. Radiat. Isot., 61, 179-183, 2004.

Hashimoto, S., Ugawa, S., Nanko, K., and Shichi, K.: The total amounts of radioactively contaminated materials in forests in Fukushima, Japan, Sci. Rep., 2, 416, doi:10.1038/srep00416, 2012.

Heldal, H. E., Føyn, L., and Varskog, P.: Bioaccumulation of ${ }^{137} \mathrm{Cs}$ in pelagic food webs in the Norwegian and Barents Seas, J. Environ. Radioact., 65, 177-185, 2003.

Higaki, T., Higaki, S., Hirota, M., Akita, K., and Hasezawa, S.: Radionuclide analysis on bamboos following the Fukushima nuclear accident, PLoS ONE, 7, e34766, doi:10.1371/journal.pone.0034766, 2012.

Honda, M. C., Aono, T., Aoyama, M., Hamajima, Y., Kawakami, H., Kitamura, M., Masumoto, Y., Miyazawa, Y., Takigawa, M., and Saino, T.: Dispersion of artificial caesium-134 and -137 in the western North Pacific one month after the Fukushima accident, Geochem. J., 46, e1-e9, 2012.

Huh, C. A., Hsu, S. C., and Lin, C. Y.: Fukushima-derived fission nuclides monitored around Taiwan: Free tropospheric versus boundary layer transport, Earth Planetary Sci. Let., 319/320, 9-14, 2012.

Kaeriyama, H., Watabe, T., and Kusakabe, M.: ${ }^{137}$ Cs concentration in zooplankton and its relation to taxonomic composition in the western North Pacific Ocean, J. Environ. Radioact., 99, 18381845, 2008a.

Kaeriyama, H., Watabe, T., and Kusakabe, M.: The concentration of ${ }^{137} \mathrm{Cs}$ and stable $\mathrm{Cs}$ in zooplankton in the western North $\mathrm{Pa}$ cific in relation to their taxonomic composition, Proceeding of the 16th Pacific Basin nuclear conference (16PBNC), paper ID: P16P1197, 2008b.

Kaeriyama, H., Ambe, D., Shimizu, Y., Fujimoto, K., Ono, T., Yonezaki, S., Kato, Y., Matsunaga, H., Minami, H., Nakatsuka, S., and Watanabe T.: Direct observation of ${ }^{134} \mathrm{Cs}$ and ${ }^{137} \mathrm{Cs}$ in surface seawater in the western and central North Pacific after the Fukushima Dai-ichi nuclear power plant accident, Biogeosciences, 10, 4287-4295, doi:10.5194/bg-10-4287-2013, 2013.

Karasev, E. V.: Monitoring of ecological conditions of the far east sea, Proceeding of the 2nd international meeting of AmurOkhotsk consortium 2011, 75-80, 2012.

Katsumata, K. and Yasuda, I.: Estimates on non-tidal exchange transport between the Sea of Okhotsk and the North Pacific, J. Oceanogr., 66, 489-504, 2010. 
Kumamoto, Y. Murata, A., Kawano, T., and Aoyama, M.: Fukushima-derived radocesium in the northwestern Pacific Ocean in February 2012, Appl. Radiat. Isot., in press, 2013.

Lalli, C. M. and Parsons, T. R.: Biological oceanography: an introduction, second edition, Butterworth-Heinemann, Oxford, 1997.

Leon, J. D., Jaffe, D. A., Kaspar, J., Knecht, A., Miller, M. L., Robertson, R. G. H., and Schubert, A. G.: Arrival time and magnitude of airborne fission products from the Fukushima, Japan, reactor incident as measured in Seattle, WA, USA, J. Environ. Radioact., 102, 1032-1038, 2011.

Madigan, D. J., Baumann, Z., and Fisher, N. S.: Pacific bluefin tuna transport Fukushima-derived radionuclides from Japan to California, Proc. Natl. Acad. Sci. USA, 109, 9483-9486, 2012.

Masson, O., Baeza, A., Bieringer, J., Brudecki, K., Bucci, S., Cappai, M., Carvalho, F. P., Connan, O., Cosma, C., Dalheimer, A., Didier, D., Depuydt, G., De Geer, L. E., De Vismes, A., Gini, L., Groppi, F., Gudnason, K., Gurriaran, R., Hainz, D., Halldórsson, Ó, Hammond, D., Hanley, O., Holeý, K., Homoki, Zs., Ioannidou, A., Isajenko, K., Jankovic, M., Katzlberger, C., Kettunen, M., Kierepko, R., Kontro, R., Kwakman, P. J. M., Lecomte, M., Leon Vintro, L., Leppänen, A.-P., Lind, B., Lujaniene, G., Mc Ginnity, P., Mc Mahon, C., Malá, H., Manenti, S., Manolopoulou, M., Mattila, A., Mauring, A., Mietelski, J. W., Møller, B., Nielsen, S. P., Nikolic, J., Overwater, R. M. W., Pálsson, S. E., Papastefanou, C., Penev, I., Pham, M. K., Povinec, P. P., Ramebäck, H., Reis, M. C., Ringer, W., Rodriguez, A., Rulík, P., Saey, P. R. J., Samsonov, V., Schlosser, C., Sgorbati, G., Silobritiene, B. V., Söderström, C., Sogni, R., Solier, L., Sonck, M., Steinhauser, G., Steinkopff, T., Steinmann, P., Stoulos, S., Sýkora, I., Todorovic, D., Tooloutalaie, N., Tositti, L., Tschiersch, J., Ugron, A., Vagena, E., Vargas, A., Wershofen, H., and Zhukova, O.: Tracking of airborne radionuclides from the damaged Fukushima Dai-Ichi nuclear reactors by European networks, Environ. Sci. Technol., 45, 7670-7677, 2011.

Melgunov, M. S., Pokhilenko, N. P., Strakhovenko, V. D., Sukhorukov, F. V., and Chuguevskii, A. V.: Fallout traces of the Fukushima NPP accident in southern West Siberia (Novosibirsk, Russia), Environ. Sci. Pollut. Res., 19, 1323-1325, 2012.

Ohtsuka, S. and Nishida, S.: Reconsideration on feeding habites of marine pelagic copepods (Crustacea), Umi no Kenkyuu, 6, 299320, 1997 (in Japanese with English abstract).
Pittauerova, D., Hettwig, B., and Fischer, H. W.: Fukushima fallout in northwest German environmental media, J. Environ. Radioact., 102, 877-880, 2011.

Povinec, P. P., Livingston, H. D., Shima, S., Aoyama, M., Gastaud, J., Goroncy, I., Hirose, K., Huynh-Ngoc, L., Ikeuchi, Y., Ito, T., La Rosa, J., Kwomg, L. L. W., Lee, S.H., Moriya, H., Mulsow, S., Oregioni, B., Pettersson, H., and Togawa, O.: IAEA'97 expedition to the NW Pacific Ocean-results of oceanographic and radionuclide investigations of the water column, Deep-Sea Res. II, 50, 2607-2637, 2003.

Sakamoto, K., Tsujino, H., Nishikawa, S., Nakano, H., and Motoi, T.: Dynamics of the Coastal Oyashio and its seasonal variation in a high-resolution Western North Pacific Ocean Model, J. Physic. Oceanogr., 40, 1283-1301, 2010.

Sawamoto, S.: Order Euphausiacea, in: An illustrated guide to marine plankton in Japan, edited by: Chihara, M. and Murano, M., Tokai Univ. Press, Tokyo, 1204-1226, 1997 (in Japanese).

Stohl, A., Seibert, P., Wotawa, G., Arnold, D., Burkhart, J. F., Eckhardt, S., Tapia, C., Vargas, A., and Yasunari, T. J.: Xenon133 and caesium-137 releases into the atmosphere from the Fukushima Dai-ichi nuclear power plant: determination of the source term, atmospheric dispersion, and deposition, Atmos. Chem. Phys., 12, 2313-2343, doi:10.5194/acp-12-2313-2012, 2012.

Tagami, K., Uchida, S., Ishii, N., and Kagiya, S.: Translocation of radiocesium from stems and leaves of plants and the effect on radiocesium concentration in newly emerged plant tissues, J. Environ. Radioact., 111, 65-69, 2012.

Taki, K.: Vertical distribution and diel migration of euphausiids from Oyashio Current to Kuroshio area off northeastern Japan, Plankton Benthos Res., 3, 27-35, 2008.

Thakur, P., Ballard, S., and Nelson, R.: Radioactive fallout in the United States due to the Fukushima nuclear plant accident, J. Environ. Monit., 14, 1317-1324, 2012.

Thomann, R. V.: Equilibrium model of fate of microcontaminants in diverse aquatic food chains, Can. J. Fish. Aquat. Sci., 38, 280 296, 1981. 